\title{
The marketing of herd health and production management services on Dutch dairy farms: Perceptions of dairy farmers and their veterinary surgeons.
}

\author{
Lievaart, J.J. ${ }^{1}$, Noordhuizen, J.P.T.M. ${ }^{2}$, Buckley, D. ${ }^{3}$ and Van Winden, S.C.L. ${ }^{4}$
}

${ }^{1}$ EH Graham Centre for Agricultural Innovation, Charles Sturt University, Wagga Wagga, NSW 2678, Australia

${ }^{2}$ Ghent University, Department of Reproduction, Faculty of Veterinary Medicine, Merelbeke, Belgium

${ }^{3}$ School of Animal and Veterinary Sciences, Charles Sturt University, Wagga Wagga,

Australia

${ }^{4}$ Veterinary Clinical Sciences, Royal Veterinary College, North Mymms, Hatfield, United Kingdom

\begin{abstract}
A questionnaire-based survey on veterinary herd health and production management services was conducted on 194 specialist dairy veterinarians and 466 dairy farmers. The farmers were randomly selected from greater than 6,000 farmer clients of the surveyed veterinarians. This paper reports these survey findings and the findings of an earlier survey conducted among the veterinarians. The survey included questions on the attributes of the service itself, the practitioners delivering the service, reasons for participation and the expected future of herd health and production management services. Reasons farmers participated in herd health and production management programmes included; access to routine screening of their herd; increasing profits; and receiving regular veterinary advice or solutions to remedy existing problems. Advantages of participation named included: good management support; higher profits; structural solutions to problems; and being better informed. Differences between farming styles were observed, pointing to the different needs and goals of farming styles. Farmers cited high costs and the time investment required as major disadvantages. The proportion of farmers citing these reasons was lower than expected by the veterinarians. In the future, preventive healthcare will be the main reason of farmers to participate. Farmers who are not using the service can potentially be encouraged to engage the services after gaining increased insight into the herd health and management service structure, the planning of activities, the cost-benefit of the service, veterinary surgeons being more co-operative with other farm advisors and veterinarians being more willing to pay attention to quality issues on the dairy farm.
\end{abstract}

Keyewords: dairy, herd health, marketing, production management service

\section{Corresponding author:}

\section{J.J. Lievaart,}

EH Graham Centre for Agricultural Innovation, Locked Bag 588,

Charles Sturt University, Wagga Wagga, NSW 2678, Australia

E-mail: jlievaart@csu.edu.au
Irish Veterinary Journal Volume 61 Number $10668-676,2008$

\section{Introduction}

Herd health and production management services by veterinarians (HHPM) have been introduced in many countries (Noordhuizen, 1984; Goodger and Kushman, 1985). Sol et al. (1984) reported the economic benefits for dairy farmers participating in HHPM programmes, but were not able to identify which components of the programme provided the economic benefits. Both the perceptions of the farmers and the veterinarians are crucial if the product is to be marketed and improved. Given that dairy farmers in European countries are confronted with increasingly quality awareness consumers, veterinarians should question the role they play in quality assurance at farm level (Hesselink et al., 1997) and whether quality assurance could be integrated in the current HHPM service (Kuiper et al., 1996; Noordhuizen and Welpelo, 1996). Moreover, farmers exporting livestock require certification on the health status of the farm. Certificates require regular animal and farm monitoring and health improvement. These activities could be part of a regular HHPM service. 
From the year 2000 onwards, a mandatory system will apply to farmers in The Netherlands. The "Quality Chain Milk" system specifies how milk should be produced and harvested (Brouwer and Franse, 1997). Non-participating farmers receive a milk price seven times lower. This system requires veterinarians to work according to principles of the Good Veterinary Practice Code. This requirement provides the veterinary surgeon with the opportunity to support farmers in optimising milk production (Rougoor, 1999), preventing diseases, decreasing costs and supporting fundamental decisions about herd health, welfare, quality and farm management in general. The veterinarians and the farmers potentially have the same goal, i.e., to produce a top quality product. This requires more veterinary input and means analysing problems and preventing disorders, with a good follow up. One of the main problems is that most farmers only contact their veterinarian for their skills or advice on problems (Lievaart et al., 1999; Lievaart and Noordhuizen, 1999). Whilst there has been initial interest in structured veterinary services, HHPM service participation is still limited. To obtain a better understanding of the demand for HHPM on dairy farms, the Veterinary Faculty of Utrecht surveyed both veterinary surgeons and farmers. The main goals of the study were to indicate problems that veterinary surgeons came across whilst introducing this service, and to make an inventory of the reasons why farmers did not want to use this service. It was also considered worthwhile to elucidate the attributes that the farmers using the programme viewed positively. Such market information will be useful in optimising the service and predicting its future role.

\section{Materials and methods}

The survey was divided into two parts. Veterinary surgeons were sent a questionnaire regarding the HHPM service. As part of the survey they provided the names of dairy farmer clients. A total of over 6,000 farmers indicated their willingness to participate. From the 6,000 farmers, a random sample of 2,250 farmers was sent a questionnaire. The questionnaire for the farmers comprised 40 questions, which were divided into five subject classes:
1. general questions about the dairy farms;

2. specific questions regarding the HHPM service on the farm;

3. specific questions about the veterinarian providing the service;

4. specific questions to farmers who do not participating in this service; and

5. specific questions regarding the expected future HHPM services.

Farmer responses were assessed in general and categorised on the size of their milk quota. Firstly, farmers with a milk quota of less than 250,000 kg milk quota (A) and secondly, farmers with quota of more than $750,000 \mathrm{~kg}$ milk (B). This classification was made because differing farming styles have been observed with increasing farm scale (Tarable and Dodd, 1990; Ploeg, 1994; Kierman and Heinrichs, 1994; Noordhuizen and Welpelo, 1996). Veterinary responses from a previous study with the same questions (Lievaart et al., 1999) were also reported. Descriptive statistical analysis of the questionnaire results was conducted using Microsoft Excel.

\section{Results}

\section{General information regarding the dairy farms}

In total 2,250 farmers received a questionnaire, 466 of the latter were returned, a response of $20.7 \%$. Table 1 shows a general profile of the responding dairy farms.

\section{Part I: Participants in HHPM service}

In total, $70.5 \%$ of the respondents participated in the HHPM service. In group A, 54.3\% took part and in group B $68.5 \%$ participated. On average, farmers had participated for 9.3 years. The HHPM service is a flexible system and components of the service will vary between farms. Some farmers only participate in routine reproduction control and feeding monitoring, while others engage with other aspects e.g., replacement rearing and husbandry. Table 2 provides an overview of the various components of the HHPM service grouped on as average and among quota groups $\mathrm{A}$ and $\mathrm{B}$.

Table 1: General information about the dairy farms

\begin{tabular}{|c|c|c|c|}
\hline & All farms & $\begin{array}{c}\text { Group A } \\
\text { (Farms with quota } \\
\leq 250,000 \mathrm{~kg} \text { ) }\end{array}$ & $\begin{array}{c}\text { Group B } \\
\text { (Farms with quota } \\
\geq 750,000 \mathrm{~kg} \text { ) }\end{array}$ \\
\hline Number of dairy farms & 466 & 23 & 53 \\
\hline Number of persons working on the farm & 1.87 & 1.51 & 2.3 \\
\hline Proportion of business dairy related (\%) & 67.8 & 21.2 & 83 \\
\hline Average size of the dairy herd & 68.4 & 35.9 & 124.2 \\
\hline Average size property (ha) & 40.6 & 36 & 84.9 \\
\hline Average quantity of milk quota (kg) & 517820 & 199500 & 985710 \\
\hline Average milk yield 305 days $<8,000 \mathrm{~kg}(\%)$ & 48.6 & 79.2 & 35.2 \\
\hline $\begin{array}{l}\text { Average milk yield } 305 \mathrm{~d} \geq 8,000<10,000 \\
\mathrm{~kg}(\%)\end{array}$ & 49.7 & 16.7 & 61.1 \\
\hline Average milk yield $305 \mathrm{~d} \geq 10,000 \mathrm{~kg}(\%)$ & 1.7 & 4.1 & 3.7 \\
\hline
\end{tabular}


Table 2: Various components of the herd health and production management service divided into routine monitoring, analysing or preventive characteristics (answers of farmers and their veterinary surgeons in \%)

\begin{tabular}{|c|c|c|c|c|}
\hline & All farms & $\begin{array}{c}\text { Group A } \\
\text { (Farms with quota } \\
\leq 250,000 \mathrm{~kg} \text { ) }\end{array}$ & $\begin{array}{c}\text { Group B } \\
\text { (Farms with quota } \\
\geq 750,000 \mathrm{~kg} \text { ) }\end{array}$ & $\begin{array}{l}\text { Veterinary } \\
\text { Surgeon }\end{array}$ \\
\hline Reproductive routine monitoring & 95.8 & 91.7 & 94.7 & 99.4 \\
\hline Ditto analysing & 22.5 & 0.0 & 23.7 & 54.0 \\
\hline Ditto preventive & 13.5 & 8.3 & 7.9 & 39.9 \\
\hline Udder health routine monitoring & 19.5 & 16.7 & 10.5 & 56.4 \\
\hline Ditto analysing & 52.6 & 50.0 & 50.0 & 73.7 \\
\hline Ditto preventive & 24.6 & 16.7 & 23.7 & 66.7 \\
\hline Claw health routine monitoring & 9.0 & 8.3 & 10.5 & 49.2 \\
\hline Ditto analysing & 18.9 & 16.7 & 21.1 & 46.9 \\
\hline Ditto preventive & 17.2 & 33.3 & 15.8 & 55.5 \\
\hline Feeding routine monitoring & 18.2 & 16.7 & 15.8 & 50.4 \\
\hline Ditto analysing & 28.5 & 25.0 & 23.7 & 71.4 \\
\hline Ditto preventive & 9.9 & 16.7 & 2.6 & 45.9 \\
\hline Replacement rearing routine monitoring & 22.2 & 8.3 & 31.6 & 52.3 \\
\hline Ditto analysing & 24.7 & 25.0 & 34.2 & 29.8 \\
\hline Ditto preventive & 32.1 & 25.0 & 31.6 & 66.4 \\
\hline Housing routine monitoring & 5.7 & 0.0 & 10.5 & NA \\
\hline Ditto analysing & 16.5 & 8.3 & 13.2 & NA \\
\hline Ditto preventive & 12.6 & 25.0 & 7.9 & NA \\
\hline Milk quality routine monitoring & 11.4 & 25.0 & 2.6 & NA \\
\hline Ditto analysing & 18.7 & 8.3 & 21.1 & NA \\
\hline Ditto preventive & 11.1 & 8.3 & 5.3 & NA \\
\hline
\end{tabular}

Reasons for using the service differed depending on the dairy farmer. Figure 1 gives an overview of reasons farmers participated. The advantages and disadvantages of participating in the HHPM service are given Figure 2 and Figure 3. This information will be of benefit to veterinary surgeons if they are to adjust veterinary services to solve the problems in a farm specific manner.

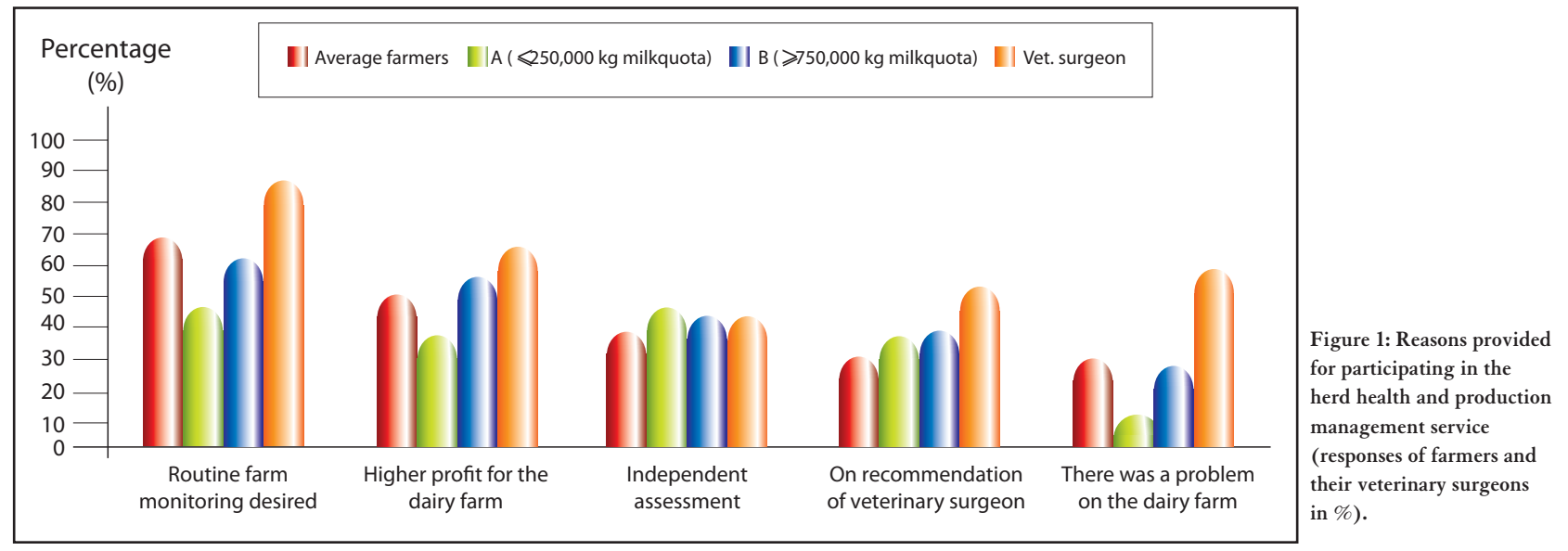




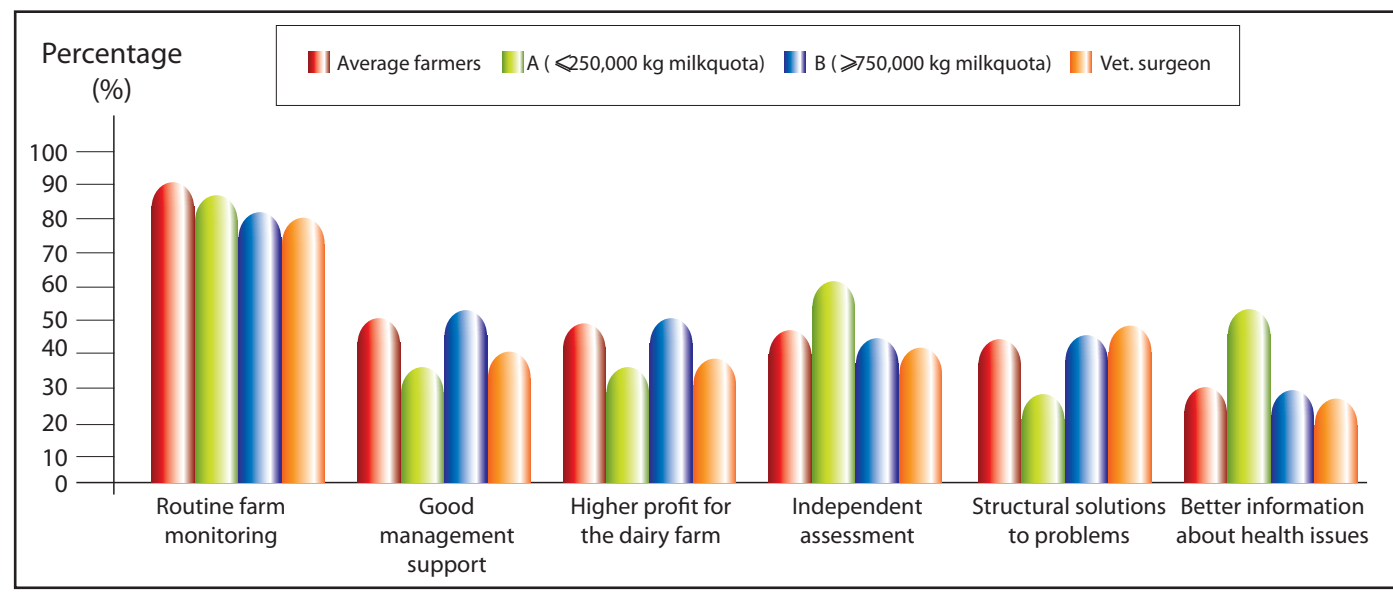

Figure 2: Advantages of participation in the herd health and production management service (responses of farmers and their veterinary surgeons

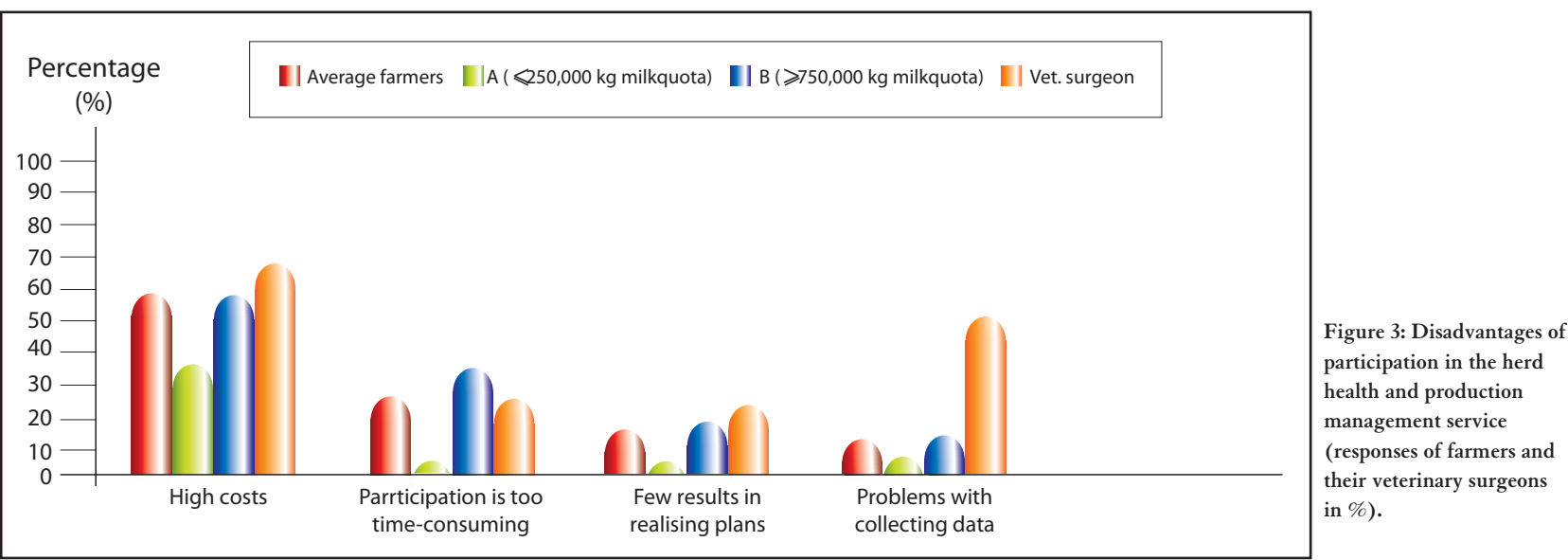

Not every component of the HHPM service will be addressed by veterinary surgeons. Farmers can also use services of other professionals and institutions. Table 3 shows involvement of non-veterinary consultants at dairy farms.

Table 3: Reasons for not participating in the herd health and production management service provided by veterinarians and alternative consultants (answers of farmers and their veterinary surgeons in $\%$ ).

\begin{tabular}{|c|c|c|c|c|}
\hline & All farms & $\begin{array}{c}\text { Group A } \\
\text { (Farms with quota } \\
\leq 250.000 \mathrm{~kg} \text { ) }\end{array}$ & $\begin{array}{c}\text { Group B } \\
\text { (Farms with quota } \\
\geq 750.000 \mathrm{~kg} \text { ) }\end{array}$ & $\begin{array}{c}\text { Veterinary } \\
\text { Surgeon }\end{array}$ \\
\hline \multicolumn{5}{|l|}{ Reproduction checks: } \\
\hline - Not interested in this area & 8.3 & 0.0 & 0.0 & 60.0 \\
\hline - Al-service does the reproduction checks & 33.3 & 0.0 & 0.0 & 75.0 \\
\hline \multicolumn{5}{|l|}{ Udder health care: } \\
\hline - Not interested in this area & 67.1 & 50.0 & 62.5 & 71.8 \\
\hline - Completed by milk factory advisors & 16.5 & 25.0 & 0.0 & 15.4 \\
\hline \multicolumn{5}{|l|}{ Claw health care: } \\
\hline - Not interested in this area & 14.0 & 37.5 & 7.4 & 38.9 \\
\hline - Completed by professional hoof trimmer & 71.7 & 44.4 & 59.3 & 77.8 \\
\hline \multicolumn{5}{|l|}{ Feeding advice: } \\
\hline - Not interested in this area & 8.8 & 12.5 & 3.4 & 24.4 \\
\hline - Completed by feed company advisors & 87.9 & 100.0 & 76.6 & 86.7 \\
\hline - Completed by agricultural extension service & 14.5 & 0.0 & 6.7 & 25.6 \\
\hline - Doubts if veterinary surgeon is right person for the job & 12.5 & 0.0 & 23.3 & 33.3 \\
\hline \multicolumn{5}{|l|}{ Replacement rearing: } \\
\hline - Not interested in this area & 59.5 & 50.0 & 12.5 & 87.7 \\
\hline - Completed by agricultural extension service & 19.8 & 50.0 & 12.5 & 4.6 \\
\hline \multicolumn{5}{|l|}{ Housing: } \\
\hline - Not interested in this area & 53.7 & 71.4 & 31.8 & NA \\
\hline - Completed by agricultural extension service & 32.7 & 28.6 & 22.7 & NA \\
\hline \multicolumn{5}{|l|}{ Milk quality advice: } \\
\hline - Not interested in this area & 39.8 & 37.5 & 37.5 & NA \\
\hline - Completed by milk factory advisors & 60.6 & 62.5 & 62.5 & NA \\
\hline
\end{tabular}


The farmers who participate in HHPM service were also asked what they would like to change in this service. The most frequently provided suggestions are shown in Figure 4.

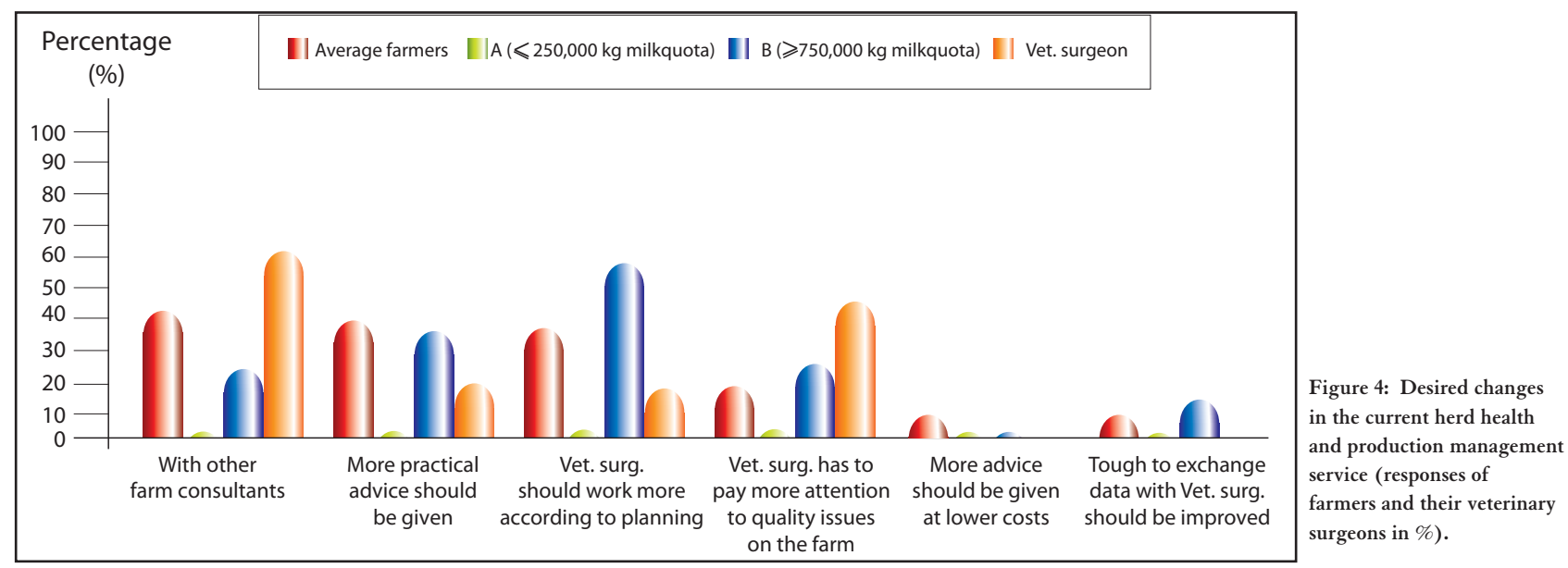

\section{Part II: Non-participants in HHPM service}

This group of farmers has never participated in the HHPM service. Veterinary surgeons, however expected them to be a potential group for the HHPM service. The reasons provided for the failure to particpate are shown in Figure 5.

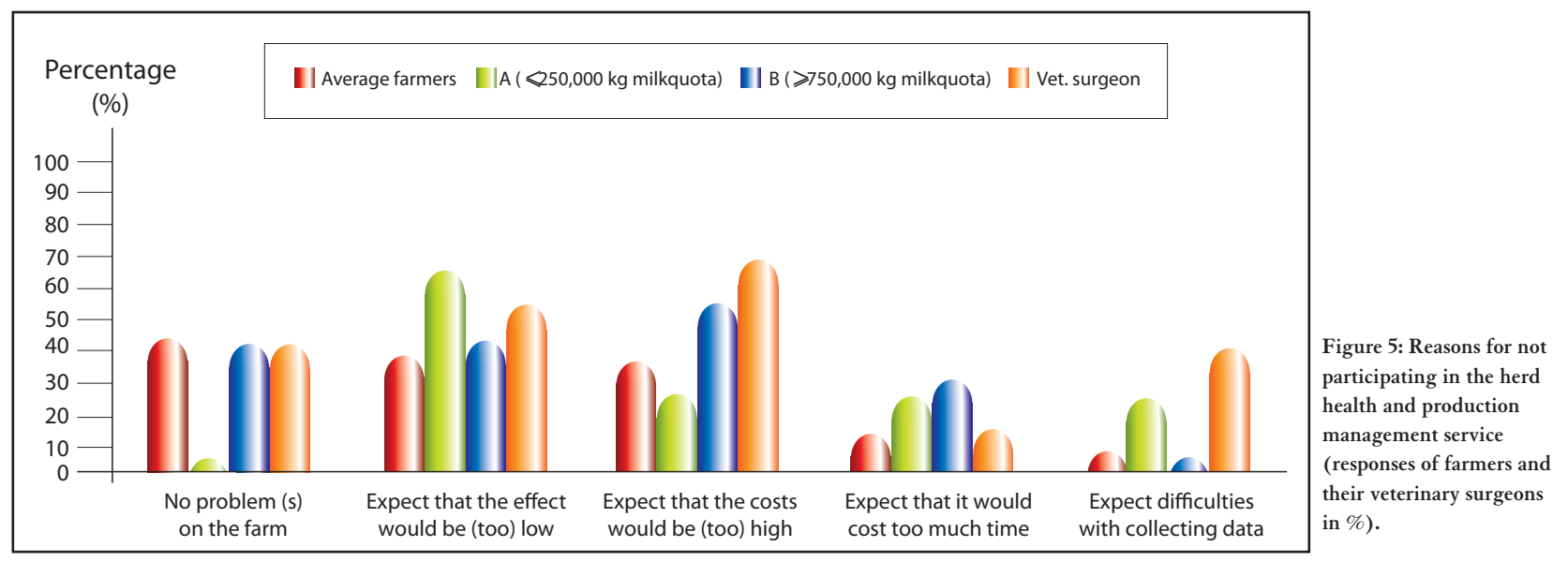

\section{Part III: Future perspectives}

Introducing or expanding HHPM services requires knowledge of the service attributes that discourage farmers from participating. At present, 39.3\% of the participating farmers were receptive to expansion of the current service levels. Farmers in group A $(27.8 \%)$ and in group B (39.5\%) wanted to expand this service in the future. In contrast, veterinarians expected increases of $92.7 \%$ to result from the introduction of compulsory farm screening (e.g., EU 97/12 or quality control based). The farmers' reasons for this expected expansion are given in Figure 6.

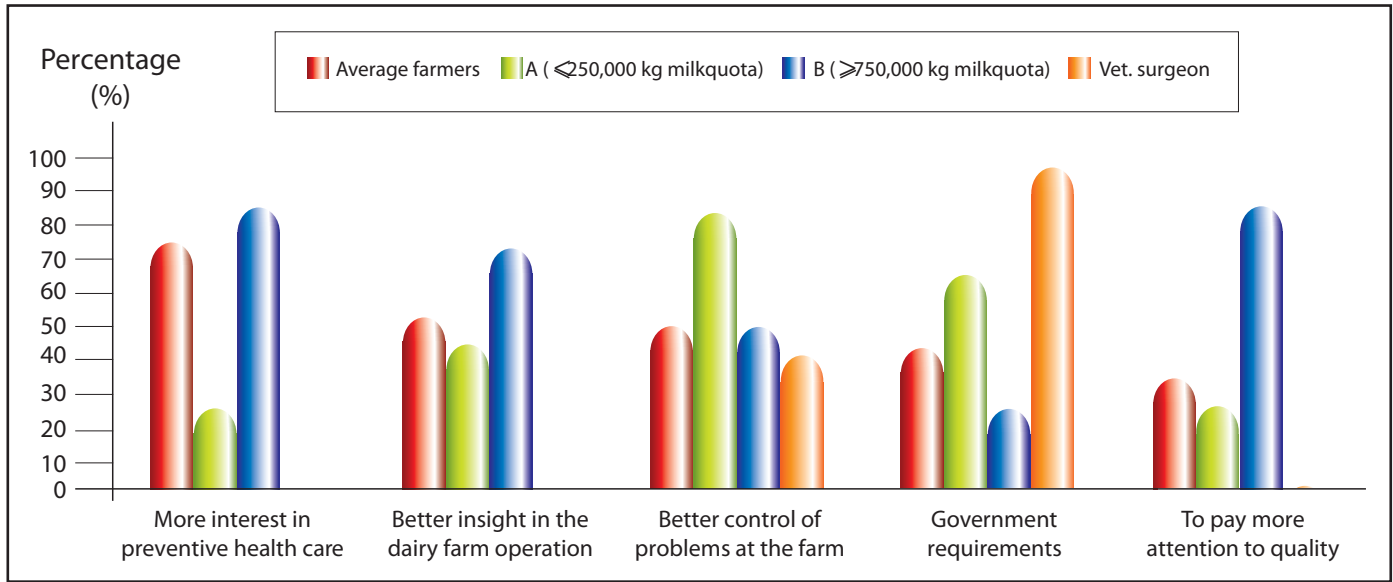

Figure 6: Reasons for expansion of the herd health and production management service(responses of farmers and their veterinary surgeons in \%). 
Farmers that are not using HHPM services are a potential market for veterinarians. Figure 7 presents service attributes that would encourage farmers to engage the service

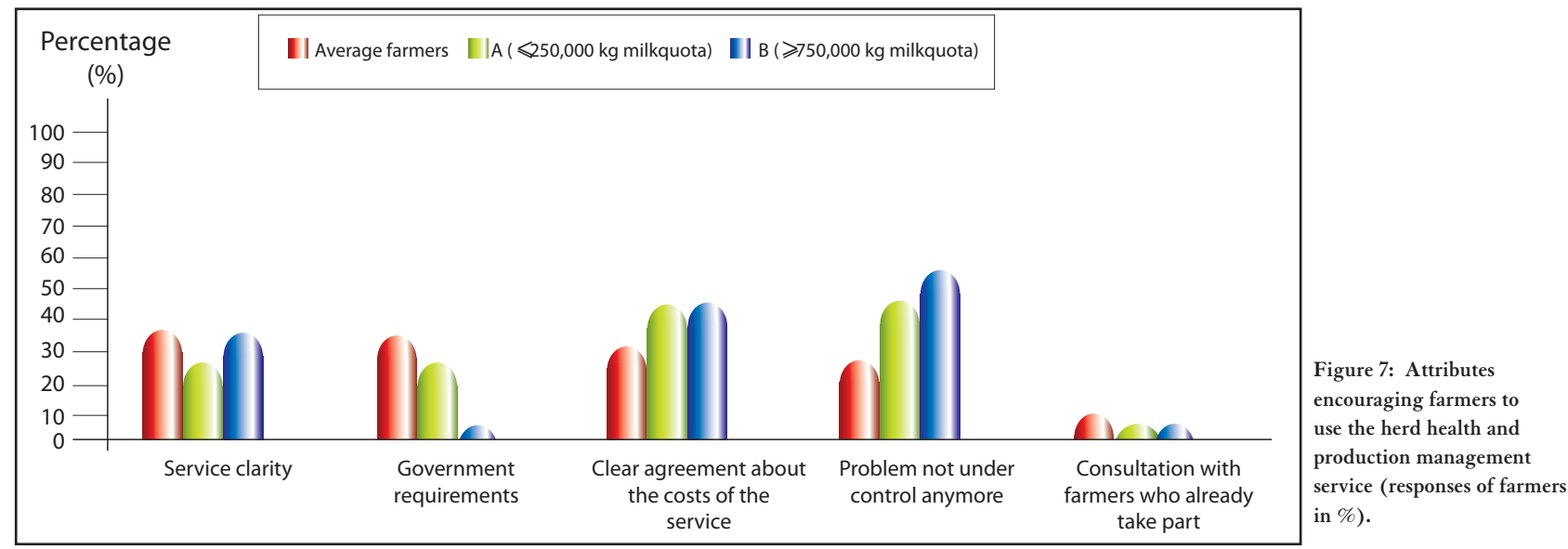

\section{Discussion}

One of the most interesting outcomes of the survey is that farmers see the direct costs and time investment as the main drawbacks for using HHPM services. The perceived disadvantages differed between veterinarians and dairy farmers. The veterinarians more frequently cited these problems. It was expected that the farmers would mention these disadvantages. It was necessary to explain to farmers that service costs not only included the cost of the farm visit, but also the veterinarians' preparation time, and time needed for problem and data analysis. The latter is usually not directly visible to the farmer and needs to be explained. On the other hand, more attention should be paid to what the HHPM service could mean to the farmer. The best way to do this is to show the farmer what problems exist on his farm (e.g., by SWOT analysis) and what the economic losses of such problems represent. Highlighting the losses associated with a certain problem, and the benefits if this problem could be controlled with a HHPM service, may convince certain farmers. It is useful for a veterinarian to make the link between solving the problem, e.g., $10 \%$ less mastitis cases, and the amount of money the farmer could save by this result (Ploeg et al., 1998). The costs and benefits should always be clarified so farmers are aware of the advantages when making use of HHPM service. On a dairy farm, the veterinarian, in association with the farmer and others, has the potential to oversee the management of the persons who can overlook many fields like feeding, reproduction, replacement rearing, udder health and claw health. Most farmers still call a veterinarian to attend for a sick cow, or when they see other signs of a disease. On the other hand, an increasing number of farmers are investing time and money in preventive healthcare. The veterinarian should use this indication for introducing a more systematic approach when a farmer calls each time for the same kind of problems (Lievaart et al., 1999). Furthermore, the routine reproductive monitoring service was the only component of the HHPM where farmers and veterinarians had a similar view. From Table 2 it is clear that the farmers don't usually understand the veterinary analysis and prevention activities. It could be that the veterinarians' clarification of the HHPM service is not sufficient. As explained before, veterinarians are concerned that the amount of time and money will prohibit farmers from participating in the HHPM service. In many cases, the veterinarian charges the farmer for a regular visit and disease medicine, even if the main part of the visit was a discussion about problems present at the farm. The benefits resulting from extra time and money spent by the farmers cannot be shown immediately. This could explain why veterinarians do not divide the HHPM service into different (mono-disciplinary) components with itemised charges. It is also interesting that farmers' opinions are related to how they perceive the role of the practitioner. One group saw the veterinarian mainly as a troubleshooter, and the other group demanded a more structured commitment and technical advice for previously identified problems. The difference is that the first group of farmers wanted an informal, more personal generalist approach, and the second group preferred a formal, business style approach. This also has implications for the way the HHPM service is going to be introduced and executed. Farmers who prefer the more informal approach only identify problems they see, and with the help of their veterinarian underlying causes can be clarified. The farmers preferring the business style already know what most of the problems are, and only need good technical advice and a structural plan on how to deal with these problems. These types of structural problems can often be solved in a HHPM service. For example, farmers from group A have a high bulk milk somatic cell count but still want the best treatment for the individual cow, farmers from group B want to look at all aspects which can cause a high cell count in their milk, and make a structural plan to find out the causes and how it can be solved and prevented. Group B farmers need special knowledge that cannot always be given by a veterinarian. It is necessary to acquire this knowledge, or hire other experts who can provide this knowledge. This can also be seen from the answers given to the question "what should change in the HHPM service?". Group A farmers did not suggest any changes, while group B 
farmers suggested a variety of modifications to the HHPM service. Cooperation with other persons and institutions was one of the answers provided by group B farmers. These farmers also wanted better and more practical advice. Aside from good clinical and surgical skills and knowledge, the complete service of HHPM requires an excellent knowledge of animal husbandry and management. This raises the issue of where the work of a veterinarian ends, and the work of an agricultural consultant begins. In the future, there must be more co-operations between veterinarians and agricultural extensions to accommodate problems, which require both specialised skills. The biggest advantage for the veterinary surgeon remains that he/she will be often the first person to engage with a problem and he/she can decide with the farmer who will be needed for more specialist advice. At the level of management, the veterinary surgeon has two primary problems. Firstly, how to demonstrate their role in solving problems while working in conjunction with agricultural consultants, and secondly how to convince farmers to use and, even more important, pay for these services. This is a dynamic process that demands a lot of time and pre-investment of the practitioner. The most important reasons cited by farmers using the service were preventive health care and insight on farm functions, which may increase profits. The different farming styles (groups $\mathrm{A}$ and $\mathrm{B}$ ) also informed potential reasons be to expand the HHPM service. Farmers in group A wanted more attention to the problems on their farms. Group B wanted a better insight on their farm, and to pay more attention to the preventive aspects of a HHPM service. Farmers not using the HHPM service at the moment are a potential group of clients for the veterinarians. For many health aspects like reproduction examination, claw health, feeding or replacement rearing, veterinarians believe that farmers had no interest. However, this was just a small group that probably never indicated to their veterinarians that they were interested. Failure to particpate reflected a lack of interest on the part of the farmers. Different methods can be used to find out which farmers are interested and which are truly not interested in health issues. For example, one could start by reviewing the most common problems of farmers who do not participate in the HHPM service (e.g., SWOT analysis). A next step could be to make a plan how to address these problems together with a timetable and prognostic approach. In some circumstances, the farmer may be convinced not to participate because the veterinarian takes the lead in solving their problems. The veterinarian has to understand that both curative work and preventive work can generate an income. Some veterinarians think that if they prevent a disease, their income will drop because there will be less curative work and less income by selling medicines. They forget that prevention of diseases will costs the same, or even more time and money, than curative approaches while the income of the farmer can decrease. Veterinarians also thought that this group of farmers and the work regarding HHPM programs had been taken over by other professionals and institutions, but up till now this has not been the case.

\section{Conclusions}

In conclusion, it appears that most of the problems veterinarians encounter are related to farmers who are unaware of the services and costs of HHPM (e.g., goals; structure; contents; operational procedures; planning; analysis) (Noordhuizen,1994; Brand et al., 1997). The marketing and provision of insight in costs and benefits of HHPM by the veterinarian will ensure a broader acceptance of HHPM service. The veterinarian will still be involved in the curative part of treating animals, but should use this as a tool to introduce the HHPM service to dairy farmers. Finally, once veterinary surgeons start to pay more attention to quality issues (Noordhuizen and Welpelo, 1996) related to the farm product (milk, meat) and the production process itself (production, health, welfare, environmental issues and quality), he/she may become more valuable to the dairy farmer as a whole farm consultant.

\section{References}

Brand, A., Noordhuizen, J.P.T.M. and Schukken Y.H. (1997). Herd Health and Production Management in Dairy Practice. First Edition. Wageningen Pers Publications.

Brouwer, J. and Franse, J.E. (1997). KKM, Keten Kwaliteit Melk: de Nederlandse melkveehouders borgen kwaliteit. Brochure, 31 pp

Goodger, W.J. and Kushman, J.E. (1985). Measuring the impact of different veterinary service programs on dairy health and milk production. Preventive Veterinary Medicine 3: 211-225.

Hesselink, J.W., Lam, T.J.G.M., Westerbeek. J.A. and Vaarten, J.L.M (1997). De rundveedierenarts na 2000: een verslag van een workshop. Tijdschrift voor Diergeneeskunde deel 122 afl. 14-15: 427-428.

Kierman, N.E. and Heinrichs, A.J. (1994). Identification of farm manager types trough cluster analysis of calf and heifer management practices. Preventive Veterinary Medicine. 18: 225-236.

Kuiper, H.A., Mengeler, M.J.B. and Noordam, M.Y. (1996). Risk assessment of residues in animal products and good veterinary practices. $31^{\text {th }}$ International Symposium on 'Food and Health: the role of animal origin', Milano, Sept.1996.

Lievaart, J.J., Noordhuizen, J.P.T.M., Daas, den N. and Jorritsma, H. (1999). Begeleiding van melkveebedrijven in Nederland: Hoe denkt de dierenarts over deelnemende en niet deelnemende veehouders. Tijdschrift voor Diergeneeskunde, deel 124. 15: 434-8.

Lievaart, J.J. and Noordhuizen, J.P.T.M. (1999). Veterinaire begeleiding van melkveebedrijven in Nederland; een situatieoverzicht vanuit de melkveehouders. Tijdschrift voor Diergeneeskunde deel 124, 24: 734-40. Noordhuizen, J.P.T.M. (1984). Veterinary herd health and production control on dairy farms. PhD thesis University of Utrecht.

Noordhuizen, J.P.T.M. and Welpelo, H.J. (1996). Sustainable improvement of animal health care by systematic quality risk management according to the HACCP concept. The Veterinary Quarterly. 18: 121-126.

Ploeg, J.D. (1994). Animal production as socio-economic system: heterogeneity, producers and perspective. In: Biological basis of sustainable animal production. Proc. $4^{\text {th }}$ Zodiac Symposium Wageningen. April 13-15, 1993.

Rougoor, C.W. (1999). Management, milk production level and economic performance. PhD thesis Wageningen Agricultural University, The Netherlands.

Sol, J. and Renkema, J.A. (1984). A three-year herd health and management program on 30 Dutch diary farms. 1. objectives and main results. The Veterinary Quarterly. 6: 141-148.

Tarable, H.D. and Dodd, K. (1990). Associations between farmers personal characteristics, management practices and farm performance. British Veterinary Journal 146: 157-164. 